\title{
Carbon isotopic evidence for the catalytic origin of light
} hydrocarbons

\author{
Frank D. Mango
}

Department of Chemical Engineering, Rice University, P.O. Box 1892, Houston, TX, 77251 , $U S A$

Received 18th July 2000, Accepted 22nd August 2000

Published on the Web 6th September 2000

The molecular proportionality between $\mathrm{C}_{6}$ and $\mathrm{C}_{7}$ isomers reported recently (F. D. Mango, Geochim. Cosmochim. Acta, 2000, 64, 1265; ref. 1) is probably the strongest evidence for catalysis yet published. It implicates two cyclopropane-like precursors, $\left[\mathrm{S}_{6}\right]$ and $\left[\mathrm{S}_{7}\right]$ (where $\mathrm{S}$ denotes any substrate), of similar structures, each yielding three isomers along similar kinetic pathways:

$$
\begin{gathered}
{\left[\mathrm{S}_{6}\right] \rightarrow n \text {-hexane }+2 \text {-methylpentane }+3 \text {-methylpentane }} \\
{\left[\mathrm{S}_{7}\right] \rightarrow n \text {-hexane }+2 \text {-methylhexane }+3 \text {-methylhexane }}
\end{gathered}
$$

This view is supported here by the carbon isotope ratios of these isomers in 36 oils from Western Canada (M. J. Whiticar and L. R. Snowdon, Org. Geochem., 1999, 30, 1127; ref. 2). They exhibit strong correlations in $\delta{ }^{13} \mathrm{C}$, consistent with their being formed in triads through isotopically indistinguishable precursors. These results add significantly to the growing body of evidence supporting catalysis.

\section{Introduction}

There can be little doubt that light hydrocarbons $\left(\mathrm{C}_{1}-\mathrm{C}_{9}\right)$ can be produced thermally from decomposing hydrocarbons in sedimentary rocks. ${ }^{3}$ Although other pathways have always seemed possible (e.g., catalysis ${ }^{4,5}$ ), they were rarely given serious consideration until it became clear that (a) ordinary hydrocarbons should remain stable under the time-temperature conditions typically seen in sedimentary rocks, ${ }^{6-9}$ and (b) thermal cracking in the laboratory does not produce a gas resembling natural gas. ${ }^{8,10-16}$ Catalysis gained additional recognition in 1987 when an invariance in isoheptanes was disclosed. ${ }^{17}$ That work introduced steady-state kinetics as a critical, if not necessary, element to light hydrocarbons (LH) genesis, thereby undermining thermal cracking as the sole explanation.

Catalysis by acidic clay minerals ${ }^{18-20}$ and reduced transition metals $^{21}$ were offered as alternative sources of LHs. However, only the latter has reproduced the composition of natural gas in the laboratory. ${ }^{22-25}$ LHs exhibit a striking molecular proportionality consistent with a catalytic origin through cyclopropane-like intermediates, ${ }^{1}$ a mechanism independently supported elsewhere. ${ }^{26,27}$ An isotopic analysis of these same hydrocarbons is reported here. The data used are from Whiticar and Snowdon ${ }^{2}$ who reported the molecular and isotopic compositions for $26 \mathrm{LHs}$ in 42 oils and condensates from Western Canada.

\section{Results and discussion}

Assume that hexane and heptane isomers originate as suggested by Mango ${ }^{1}$ and illustrated in Fig. 1.

If the kinetic pathways $\left[\mathrm{S}_{6}\right] \rightarrow\left[n-\mathrm{C}_{6}+2-\mathrm{MP}+3-\mathrm{MP}\right]$ and $\left[\mathrm{S}_{7}\right]$ $\rightarrow\left[n-\mathrm{C}_{7}+2-\mathrm{MH}+3-\mathrm{MH}\right]$ are energetically similar, as would be the case in Fig. 1 for example, then the following proportionality obtains:

$$
\left[\left(n-\mathrm{C}_{6}\right)(\mathrm{MHs})\right] /\left[(\mathrm{MPs})\left(n-\mathrm{C}_{7}\right)\right]=\alpha
$$

(where MHs $=2$-methylhexane +3 -methylhexane; MPs $=2$ methylpentane +3 -methylpentane).

The LH in crude oils obey eqn. (1) to a remarkable degree. Fig. 2 shows the correlation between $\left[\left(n-\mathrm{C}_{6}\right)(\mathrm{MHs})\right]$ and $\left[(\mathrm{MPs})\left(n-\mathrm{C}_{7}\right)\right]$ in concentrations of wt. $\%$ total oil $\left(r^{2}=0.99\right.$; ref. 1$). \alpha$ is tightly constrained to a mean of 0.75 with a standard deviation ( $s$ ) of 0.20 (mean centered), significantly below those of the ratios composing $\alpha: s=0.42$ for $\left(n-\mathrm{C}_{6} / n-\mathrm{C}_{7}\right), 0.46$ for $(n$ $\left.\mathrm{C}_{6} / \mathrm{MPs}\right), 0.51$ for $\left(n-\mathrm{C}_{6} / \mathrm{MHs}\right)$, and 0.41 for (MPs/MHs). Moreover, the variability of $\alpha$ is unique to its particular
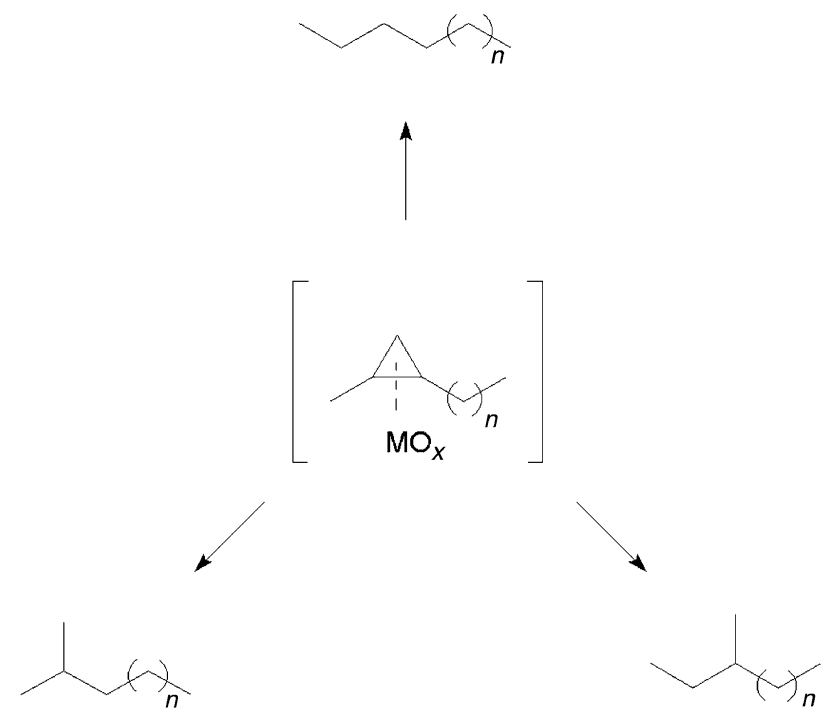

Fig. 1 A kinetic scheme for catalytic isomerization through a cyclopropane-reduced metal oxide intermediate: $\left[\mathrm{S}_{6}\right](n=1)$, and $\left[\mathrm{S}_{7}\right]$ $(n=2)$; Fig. 1 of Mango. ${ }^{1}[\mathrm{~S}]$ is a cyclopropyl-transition metal complex formed from some substrate $\mathrm{S}$. The actual structure of $[\mathrm{S}]$ is unspecified and should not be inferred from the figure (see Mango ${ }^{1}$ for discussion). Cyclopropanes may or may not exist as distinct entities. However, their inclusion as distinct entities coordinated to a catalytic site best illustrates the hypothetical process where three isomers are kinetically linked to a common intermediate.

This journal is $\mathbb{C}$ The Royal Society of Chemistry and the Division of Geochemistry of the American Chemical Society 2000 


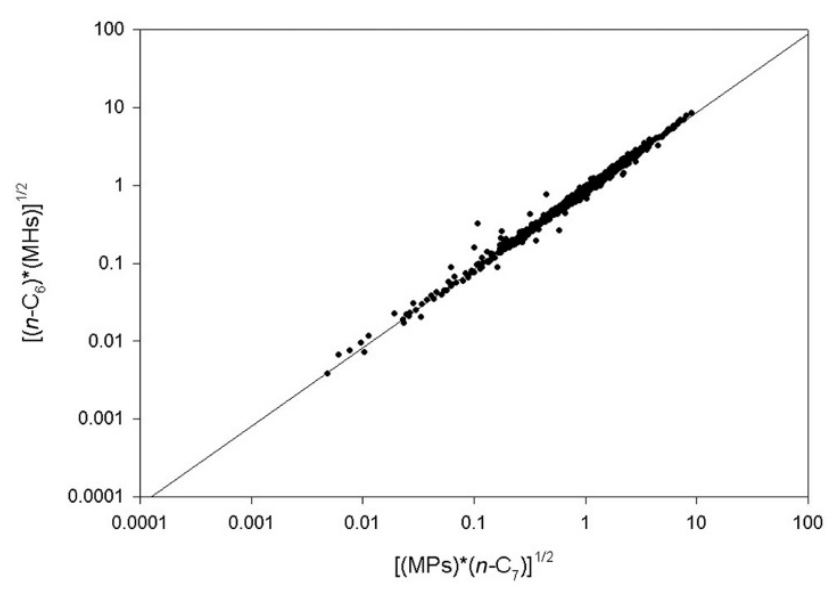

Fig. 2 A plot of $\left[\left(n-\mathrm{C}_{6}\right)^{*}(\mathrm{MHs})\right]^{1 / 2}$ vs. $\left[(\mathrm{MPs})^{*}\left(n-\mathrm{C}_{7}\right)\right]^{1 / 2}$ for 900 crude oils; Fig. 2 in Mango (ref. 1). MHs $=(2-\mathrm{MH}+3-\mathrm{MH}) ; \mathrm{MPs}=(2-\mathrm{MP}+$ 3-MP). Concentrations are in wt.\% total oil. The data are plotted as square root to constrain the scale to average concentrations. The line is the linear regression line: intercept $=-0.068$; slope $=1.01 ; r^{2}=0.991$. Mean for the ratio $\left[\left(n-\mathrm{C}_{6}\right) *(\mathrm{MHs})\right] /\left[(\mathrm{MPs}) *\left(n-\mathrm{C}_{7}\right)\right]=0.75 \pm 0.31 \mathrm{~s}$. Mean-centered $\mathrm{s}=0.20$.

combination of product functions. Its $s$ of 0.20 increases by a factor of four in $[(\mathrm{MPs})(\mathrm{MHs})] /\left[\left(n-\mathrm{C}_{6}\right)\left(n-\mathrm{C}_{7}\right)\right]$ and by a factor of almost five in $\left[\left(n-\mathrm{C}_{7}\right)(\mathrm{MHs})\right] /\left[\left(n-\mathrm{C}_{6}\right)(\mathrm{MPs})\right]$ (ref. 1). Thus, at all concentrations, $\left[\left(n-\mathrm{C}_{6}\right)(\mathrm{MHs})\right]$ and $\left[(\mathrm{MPs})\left(n-\mathrm{C}_{7}\right)\right]$ express a strong and significant correlation in crude oils, perhaps the strongest yet disclosed among LHs, while $\alpha$ remains nearly constant.

This relationship establishes a genetic link between $\left[n-\mathrm{C}_{6}+2-\right.$ $\mathrm{MP}+3-\mathrm{MP}]$ and $\left[n-\mathrm{C}_{7}+2-\mathrm{MH}+3-\mathrm{MH}\right]$ pointing to structurally similar precursors. It would be reinforced if it could also be shown that the six LH reflect isotopically similar precursors. Although $\delta{ }^{13} \mathrm{C}$ for $\left[\mathrm{S}_{6}\right]$ and $\left[\mathrm{S}_{7}\right]$ cannot be measured directly, they can be calculated from the weighted sums:

$$
\begin{aligned}
& \delta^{13} \mathrm{C}\left(\left[\mathrm{S}_{6}\right]\right)=a \delta^{13} \mathrm{C}(2-\mathrm{MP})+b \delta^{13} \mathrm{C}(3-\mathrm{MP}) \\
& +c \delta^{13} \mathrm{C}\left(n-\mathrm{C}_{6}\right) \\
& \delta^{13} \mathrm{C}\left(\left[\mathrm{S}_{7}\right]\right)=d \delta^{13} \mathrm{C}(2-\mathrm{MP})+e \delta^{13} \mathrm{C}(3-\mathrm{MP}) \\
& +f \delta^{13} \mathrm{C}\left(n-\mathrm{C}_{6}\right)
\end{aligned}
$$

(where $a, b$ and $c(d, e$, and $f)$ are the molecular fractions of the respective isomers; $a+b+c=1$, and $d+e+f=1$ ). Thus, $\delta$ ${ }^{13} \mathrm{C}$ 's for $\left[\mathrm{S}_{6}\right]$ and $\left[\mathrm{S}_{7}\right]$ can be calculated from the $\delta{ }^{13} \mathrm{C}$ 's and molecular fractions of the six isomers.

Whiticar and Snowdon ${ }^{2}$ published this data for the LH in 42 oils from Western Canada. Table 1 was constructed from their data. It contains 36 of their oils, including all with sufficient data to calculate $\delta{ }^{13} \mathrm{C}\left(\left[\mathrm{S}_{6}\right]\right)$ and $\delta{ }^{13} \mathrm{C}\left(\left[\mathrm{S}_{7}\right]\right)$ except for two, possibly altered oils. Fig. 3 shows $\left[\mathrm{S}_{6}\right]$ to be isotopically indistinguishable from $\left[\mathrm{S}_{7}\right]$. The mean for $\delta{ }^{13} \mathrm{C}\left(\left[\mathrm{S}_{6}\right]\right) / \delta{ }^{13} \mathrm{C}$ $\left(\left[\mathrm{S}_{7}\right]\right)=1.00 \pm 0.024 \mathrm{~s}$, which is within the experimental error reported for this data $( \pm 0.5 s)$.

Table 1 Light hydrocarbon data taken from Whiticar and Snowdon. ${ }^{2} \delta^{13} \mathrm{C}$ values are averages of multiple analyses. $\delta{ }^{13} \mathrm{C}[\mathrm{C} 6]$ and $\delta{ }^{13} \mathrm{C}[\mathrm{C} 7]$ (the last two columns) were calculated from eqn. (2) and eqn. (3), respectively with coefficients $a, b$ and $c$ calculated from the respective $\mathrm{C}_{6}$ concentrations normalized to 1 and coefficients $d$, $e$, and $f$ calculated from the respective $\mathrm{C}_{7}$ concentrations normalized to 1 . The amount of 2-MP (in $\%$ ) was taken from column five of Whiticar-Snowdon's Table 3 labeled 3DMC4 incorrectly. Six oils in Whiticar-Snowdon's set of 42 oils were excluded from this

\begin{tabular}{|c|c|c|c|c|c|c|c|c|c|c|c|c|c|c|}
\hline & $\begin{array}{l}2 \mathrm{MP} \\
(\%)\end{array}$ & $\begin{array}{l}3 \mathrm{MP} \\
(\%)\end{array}$ & $\begin{array}{l}n \mathrm{C} 6 \\
(\%)\end{array}$ & $\begin{array}{l}\delta^{13} \mathrm{C} \\
2 \mathrm{MP}\end{array}$ & $\begin{array}{l}\delta{ }^{13} \mathrm{C} \\
3 \mathrm{MP}\end{array}$ & $\begin{array}{l}\delta_{\mathrm{C} 6}^{13} \mathrm{C} n \\
\end{array}$ & $\begin{array}{l}2 \mathrm{MH} \\
(\%)\end{array}$ & $\begin{array}{l}3 \mathrm{MH} \\
(\%)\end{array}$ & $\begin{array}{l}n \mathrm{C} 7 \\
(\%)\end{array}$ & $\begin{array}{l}\delta{ }^{13} \mathrm{C} \\
2 \mathrm{MH}\end{array}$ & $\begin{array}{l}\delta{ }^{13} \mathrm{C} \\
3 \mathrm{MH}\end{array}$ & $\begin{array}{l}\delta{ }^{13} \mathrm{C} \\
n \mathrm{C} 7\end{array}$ & $\begin{array}{l}\delta^{13} \mathrm{C} \\
{[\mathrm{C} 6]}\end{array}$ & $\begin{array}{l}\delta^{13} \mathrm{C} \\
{[\mathrm{C} 7]}\end{array}$ \\
\hline Blueberry & 5.48 & 3.89 & 4.13 & -28.3 & -27.45 & -28.1 & 8.09 & 7.08 & 3.42 & -26.65 & -27.9 & -28.9 & -27.9939 & -27.5400 \\
\hline Bonanza & 6.27 & 4.56 & 4.94 & -29.03 & -29.4 & -30 & 3.3 & 5.67 & 2.86 & -28.9 & -29.47 & -30.8 & -29.4408 & -29.6325 \\
\hline Brazeau C & 4.49 & 3.29 & 3.26 & -27.9 & -25.7 & -29.7 & 2.53 & 4.16 & 2.3 & -26.6 & -26.8 & -30.5 & -27.7759 & -27.6903 \\
\hline Brazeau D & 1.67 & 1.28 & 3.49 & -26.8 & -25 & -29 & 3.25 & 4.3 & 10.09 & -26.2 & -26.8 & -29.9 & -27.6345 & -28.4626 \\
\hline Brazeau M & 4.72 & 3.28 & 2.44 & -24.6 & -24.25 & -26.5 & 5.52 & 4.58 & 1.45 & -24.2 & -25.3 & -27.2 & -24.9341 & -25.0128 \\
\hline Brazeau Y & 2.39 & 1.75 & 3.79 & -21.8 & -21.9 & -23.7 & 6.92 & 5.56 & 11.16 & -21.6 & -23.5 & -24.8 & -22.7301 & -23.5575 \\
\hline Cecil & 5.58 & 4.18 & 2.86 & -28.6 & -27.6 & -29.4 & 3.95 & 6.35 & 2.26 & -26.5 & -27.9 & -29.5 & -28.4501 & -27.7476 \\
\hline Cherhill & 6.34 & 4.98 & 3.91 & -27.5 & -26.3 & -28.8 & 3.93 & 7.22 & 3.46 & -25.6 & -26.55 & -29.1 & -27.4414 & -26.8984 \\
\hline C. del Bonita & 8.78 & 5.95 & 6.41 & -27.2 & -26.7 & -28.4 & 9.91 & 5.49 & 1.72 & -26.3 & -27.2 & -29 & -27.4231 & -26.8599 \\
\hline Dunvegan & 2.9 & 1.88 & 6.34 & -25.1 & -24.8 & -26 & 4.02 & 4.01 & 12.91 & -24 & -26.1 & -26.7 & -25.5624 & -26.0668 \\
\hline Foothills 12 & 3.7 & 2.37 & 7.57 & -25.1 & -23.8 & -25.4 & 6.21 & 5.06 & 12.62 & -24.2 & -25.9 & -26.5 & -25.0406 & -25.7751 \\
\hline Glenevis & 8.89 & 6.06 & 5.86 & -27.5 & -26.85 & -28.1 & 5.44 & 6.36 & 2.53 & -25.55 & -27.2 & -28.5 & -27.4797 & -26.8031 \\
\hline Home 34 & 3.64 & 2.33 & 6.95 & -25.3 & -25.3 & -25.9 & 6.1 & 4.84 & 11.38 & -24.9 & -26.3 & -27 & -25.6228 & -26.2743 \\
\hline Hutch & 6.12 & 5.59 & 1.78 & -26.7 & -25.9 & -27.1 & 4.09 & 7.16 & 1.21 & -23.9 & -25.6 & -27.4 & -26.4213 & -25.2168 \\
\hline Loon & 3.4 & 2.82 & 1.75 & -27.4 & -25.6 & -29.3 & 2.51 & 4.33 & 1.49 & -25.3 & -26.25 & -29.5 & -27.1803 & -26.5451 \\
\hline Lousana & 4.62 & 4.22 & 1.95 & -28.7 & -26.3 & -30.1 & 1.6 & 3.64 & 1.03 & -26.2 & -27.1 & -30.7 & -28.0144 & -27.4617 \\
\hline Medicine River & 5.14 & 3.58 & 4.2 & -25.55 & -24.95 & -25.7 & 5.04 & 5.71 & 3.41 & -24.2 & -26.15 & -26.55 & -25.4325 & -25.5523 \\
\hline Miracle 1 & 6.05 & 3.73 & 9.54 & -26 & -25.2 & -26.4 & 6.44 & 5.03 & 9.01 & -24.7 & -26.1 & -27 & -26.0431 & -26.0557 \\
\hline Moose Mtm & 4.92 & 3.93 & 6.42 & -24.55 & -23.85 & -25.85 & 9.64 & 6.34 & 6.74 & -23.85 & -23.9 & -25.9 & -24.9164 & -24.4721 \\
\hline Moose Mtm 2 & 3.77 & 2.89 & 8.24 & -24.7 & -23 & -25.3 & 7.17 & 4.71 & 13.38 & -23.2 & -23.6 & -25.8 & -24.7021 & -24.6518 \\
\hline Otter & 4.22 & 2.98 & 6.7 & -27.8 & -26.1 & -29.7 & 1.97 & 4.66 & 9.65 & -26 & -26.7 & -29.9 & -28.3514 & -28.5121 \\
\hline Plato & 5.26 & 4.11 & 2.88 & -25.9 & -25.5 & -26.9 & 4.19 & 5.49 & 1.11 & -23.9 & -25.8 & -27.4 & -26.0009 & -25.2268 \\
\hline Provost & 5.21 & 3.68 & 3.61 & -25.9 & -26 & -26 & 4.92 & 5.5 & 2.59 & -24.4 & -26.2 & -26.9 & -25.9583 & -25.6586 \\
\hline Rainbow 1 & 5.49 & 4.09 & 8.5 & -25.55 & -24 & -27.75 & 5.15 & 7.1 & 14.13 & -23.9 & -24.2 & -28.9 & -26.2337 & -26.6589 \\
\hline Rainbow 2 & 3.85 & 3.3 & 6.36 & -26.9 & -25.2 & -29.3 & 5.05 & 7.48 & 14.11 & -24.3 & -24.7 & -28.4 & -27.6146 & -26.5839 \\
\hline Redwater & 3.55 & 2.8 & 4.78 & -27.5 & -25.8 & -29 & 3.11 & 4.68 & 8.05 & -25.6 & -26.4 & -29.9 & -27.7165 & -28.0217 \\
\hline Rycroft & 4.15 & 2.83 & 7.1 & -27.05 & -26.01 & -29.15 & 3.78 & 4.92 & 11.89 & -27.25 & -28.9 & -30.95 & -27.8999 & -29.7809 \\
\hline S. Eureka & 4.91 & 3.23 & 7.48 & -26.5 & -26 & -27.15 & 5.48 & 4.81 & 9.22 & -24.85 & -26.5 & -27.95 & -26.7079 & -26.7218 \\
\hline Sage Creek & 0.64 & 0.56 & 0.97 & -25.15 & -25.25 & -24.9 & 5.56 & 4.77 & 8.8 & -23.2 & -25.55 & -25.55 & -25.0641 & -24.8670 \\
\hline Sylvan Lake & 6 & 4.21 & 4.03 & -25.9 & -25.8 & -25.8 & 2.13 & 5.29 & 2.19 & -24.25 & -25.3 & -25.55 & -25.8421 & -25.1242 \\
\hline Turner Valley & 0.78 & 0.66 & 1.26 & -23.3 & -22.8 & -24.05 & 4.88 & 5.78 & 7.53 & -22.7 & -24.1 & -25.4 & -23.5278 & -24.2626 \\
\hline Virginia Hills & 4.71 & 3.51 & 7.86 & -24.9 & -24.3 & -26.9 & 8.27 & 6.44 & 7.19 & -24.55 & -25.35 & -28.1 & -25.7466 & -25.9508 \\
\hline Wainwright & 6.19 & 4.19 & 3.19 & -25.7 & -25.6 & -26 & 5.76 & 6.78 & 1.69 & -23.8 & -25.8 & -26.5 & -25.7396 & -25.0736 \\
\hline Wallesden Gr. & 5.05 & 3.83 & 4.37 & -26.5 & -25.8 & -27.7 & 4.62 & 5.7 & 2.91 & -24.7 & -26.3 & -27.9 & -26.6934 & -26.0932 \\
\hline Wembley & 5.44 & 3.38 & 6.71 & -29.7 & -28.5 & -30.4 & 4.93 & 6.04 & 6.14 & -28.1 & -28.9 & -30.8 & -29.7413 & -29.3513 \\
\hline Zama & 4.71 & 3.06 & 7.66 & -25.9 & -25.3 & -28 & 5.19 & 6.74 & 15.43 & -23.4 & -24.8 & -28.8 & -26.8235 & -26.7903 \\
\hline
\end{tabular}
set: Brazeau PA was excluded because of possible thermochemical sulfate reduction (TSR), Fusilier was not included because of low $n$-alkanes and thus possible biodegradation. Four other oils were excluded because they did not contain the full suite of data required to calculate $\delta{ }^{13} \mathrm{C}$ [C6] and $\delta$ ${ }^{13} \mathrm{C}$ [C7]: Brazeau River F, Chester, Foothills 8, and Manyberries 


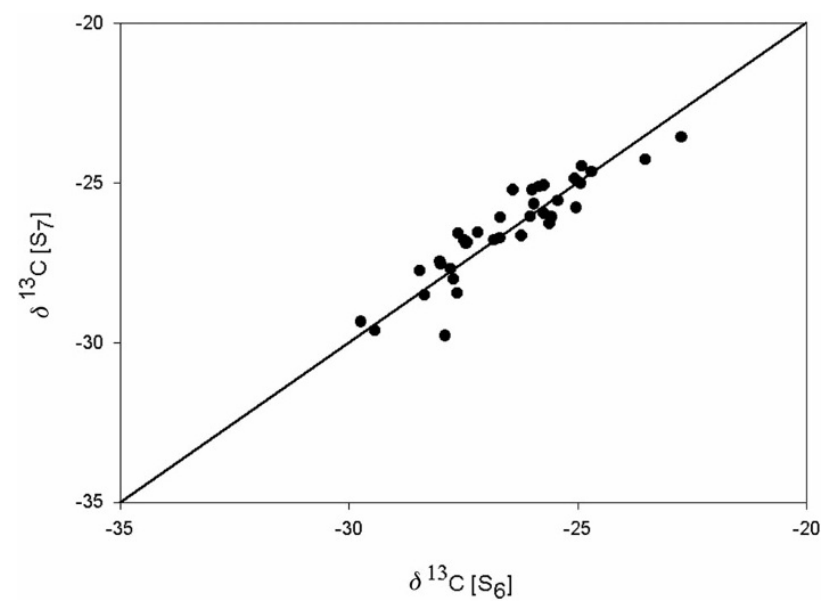

Fig. 3 A plot of carbon isotope ratios $(\%)$ for presumed intermediates $\left[\mathrm{S}_{6}\right]$ and $\left[\mathrm{S}_{7}\right]$, where $\delta{ }^{13} \mathrm{C}\left(\left[\mathrm{S}_{6}\right]\right)=a \delta^{13} \mathrm{C}(2-\mathrm{MP})+b \delta{ }^{13} \mathrm{C}(3-\mathrm{MP})+c \delta$ ${ }^{13} \mathrm{C}\left(n-\mathrm{C}_{6}\right)$ and $\delta{ }^{13} \mathrm{C}\left(\left[\mathrm{S}_{7}\right]\right)=d \delta{ }^{13} \mathrm{C}(2-\mathrm{MH})+e \delta{ }^{13} \mathrm{C}(3-\mathrm{MH})+f \delta{ }^{13} \mathrm{C}$ $\left(n-\mathrm{C}_{7}\right)$. Data shown in Table 2. The reported analytical error for $\delta^{13} \mathrm{C}$ 's is $\pm 0.5 \% 0$ s (ref. 2). The mean for $\delta{ }^{13} \mathrm{C}\left(\left[\mathrm{S}_{6}\right]\right) / \delta{ }^{13} \mathrm{C}\left(\left[\mathrm{S}_{7}\right]\right)=1.00 \pm$ $0.02 s$. For the linear regression, $r^{2}=0.83$, slope $=0.90$ and intercept $=-$ 2.48

Fig. 2 (ref. 1) provides molecular evidence for structurally similar precursors, like the hypothetical intermediates $\left[\mathrm{S}_{6}\right]$ and $\left[\mathrm{S}_{7}\right]$ in Fig. 1. Fig. 3 is consistent with this, implicating isotopically indistinguishable precursors. Whiticar and Snow$\mathrm{don}^{2}$ came to a similar conclusion: "these isotopic distributions among isomers are strong evidence suggesting that the formation of these gasoline-range hydrocarbons is intricately linked to the isotopic signature of the precursor molecules from which they are derived".

Fig. 3 does not exclude the conventional view that $\mathrm{LH}$ are thermal descendents of higher isoprenoids and $n$-alkanes (ref. 28). But it is difficult to explain the two correlations (Fig. 2 and 3 ) by this mechanism. They suggest a catalytic agent guiding the course of reaction through structurally similar intermediates. Irrespective of how these six LH might originate (catalytically or thermally), however, their molecular and isotopic correlations establish a genetic link $(\leftrightarrow)$ between $n$ alkanes and isoalkanes that traverses carbon number and is fundamental to the origin of $\mathrm{LH}$ :

$$
\left[n-\mathrm{C}_{6} \leftrightarrow 2-\mathrm{MP} \leftrightarrow 3-\mathrm{MP}\right] \leftrightarrow\left[n-\mathrm{C}_{7} \leftrightarrow 2-\mathrm{MH} \leftrightarrow 3-\mathrm{MH}\right]
$$

\section{Acknowledgements}

I am grateful to the US Department of Energy for Grant DEFG05-92ER14295. I thank Alan Young for his review of the manuscript and helpful comments.

\section{References}

1 F. D. Mango, The origin of light hydrocarbons, Geochim Cosmochim. Acta, 2000, 64, 1265.

2 M. J. Whiticar and L. R. Snowdon, Geochemical characterization of selected Western Canada oils by C5-C8 compound specific isotope correlation (CSIC), Org. Geochem., 1999, 30, 1127.

3 F. D. Mango, The light hydrocarbons in petroleum: a critical review, Org. Geochem., 1997, 26, 417.

4 A. V. Frost, The role of clays in the formation of petroleum, Usp. Khim., 1945, 14, 501.
5 R. E. Grim, Relation of clay mineralogy to origin and recovery of petroleum, Am. Assoc. Petr. Geol. Bull., 1947, 31, 1491.

6 H. J. Schenk, R. Di Primio and B. Horsfield, The conversion of oil into gas in petroleum reservoirs. Part 1: Comparative kinetic investigation of gas generation from crude oils of lacustrine, marine and fluviodeltaic origin by programmed-temperature closed-system pyrolysis, Org. Geochem., 1997, 26, 467.

7 K. J. Jackson, A. K. Burnham, R. L. Braun and K. G. Knauss, Temperature and pressure dependence of $n$-hexadecane cracking, Org. Geochem., 1995, 23, 941.

8 A. K. Burnham, H. R. Gregg, R. L. Ward, K. G. Knauss, S. A. Copenhaver, J. G. Reynolds and R. Sanborn, Decomposition kinetics and mechanism of $n$-hexadecane-1,2- ${ }^{13} \mathrm{C}_{2}$ and dodec1-ene-1,2- ${ }^{13} \mathrm{C}_{2}$ doped in petroleum and $n$-hexadecane, Geochim. Cosmochim. Acta, 1997, 61, 3725.

9 F. Domine, D. Dessort and O. Brevart, Towards a new method of geochemical kinetic modeling: implications for the stability of crude oils, Org. Geochem., 1998, 28, 597.

10 J. G. McNab, P. V. Smith and R. L. Betts, The evolution of petroleum, Petr. Eng. Chem., 1952, 44, 2556.

11 R. J. Evans and G. T. Felbeck, High temperature simulation of petroleum formation I. The pyrolysis of Green River Shale, Org. Geochem., 1983, 4, 135.

12 J. D. Saxby and K. W. Riley, Petroleum generation by laboratoryscale pyrolysis over six years simulating conditions in a subsiding basin, Nature, 1984, 308, 177.

13 J. Espitalie, P. Ungerer, I. Irwin and F. Marquis, Primary cracking of kerogens. Experimenting and modeling C1, C2-C5, C6-C15 and C15+ classes of hydrocarbons formed, Org. Geochem., 1987, 13, 893

14 T. Hikita, I. Takahashi and T. Yoshimichi, Hydropyrolysis of heavy oils, Fuel, 1989, 68, 1140.

15 B. Horsfield, H. J. Schenk, N. Mills and D. H. Welte, An investigation of the in-reservoir conversion of oil to gas: Compositional and kinetic findings from closed-system programmed-temperature pyrolysis, Org. Geochem., 1992, 19, 191.

16 M. Vandenbroucke, F. Behar and J. L. Rudkiewicz, Kinetic modeling of petroleum formation and cracking: implications from the high pressure/high temperature Elgin Field (UK, North Sea), Org. Geochem., 1999, 30, 1105.

17 F. D. Mango, An invariance in the isoheptanes of petroleum, Science, 1987, 273, 514

18 T. P. Goldstein, Geocatalytic reactions in formation and maturation of petroleum, Am. Assoc. Petr. Geol. Bull., 1983, 67, 152.

19 Y. V. Kissin, Catagenesis and composition of petroleum: Origin of $n$-alkanes and isoalkanes in petroleum crudes, Geochim. Cosmochim. Acta, 1987, 51, 2445.

20 Y. V. Kissin, Catagenesis of light cycloalkanes in petroleum, Org Geochem., 1990, 15, 575.

21 F. D. Mango, Transition metal catalysis in the generation of petroleum and natural gas, Geochim. Cosmochim. Acta, 1992, 56, 553.

22 F. D. Mango, J. W. Hightower and A. T. James, Role of transition-metal catalysis in the formation of natural gas, Nature, 1994, 368, 536

23 F. D. Mango, Transition metal catalysis in the generation of natural gas, Org. Geochem., 1996, 24, 977.

24 F. D. Mango and J. Hightower, The catalytic decomposition of petroleum into natural gas, Geochim. Cosmochim. Acta, 1997, 24, 5347.

25 F. D. Mango and L. W. Elrod, The carbon isotopic composition of catalytic gas: A comparative analysis with natural gas, Geochim. Cosmochim. Acta, 1999, 63, 1097.

26 A. C. T. Van Duin and S. R. Larter, Unraveling Mango's mysteries: a kinetic scheme describing the diagenetic fate of C7alkanes in petroleum systems, Org. Geochem., 1997, 27, 597.

27 Y. Xiao and A. G. James, Is acid catalyzed isomerization responsible for the invariance in the isoheptanes of petroleum, 18th Int. Meeting Org. Geochem., Maastricht, 1997, Abstracts Part II, pp. 769-770.

28 Y. V. Kissin, Org. Geochem., 1993, 20, 1077. 